\title{
Recurrent Malignant Ovarian Granulosa Cell Tumor
}

National Cancer Institute

\section{Source}

National Cancer Institute. Recurrent Malignant Ovarian Granulosa Cell Tumor. NCI

Thesaurus. Code C160619.

The reemergence of malignant ovarian granulosa cell tumor after a period of remission. 